\title{
Neglected rare human parasitic infections: Part III: Acanthocephaliasis \\ Review
}

Article

\author{
Wael M Lotfy
}

Department of Community Health Nursing, Faculty of Nursing, Matrouh University, Egypt

\begin{abstract}
Human acanthocephaliasis is a zoonotic parasitic infection with acanthocephalan species. Reports documenting human infection with acanthocephalans are relatively rare in the literature. Nonetheless, man has been infected with acanthocephalans since ancient times. Despite their economic and medical significance, acanthocephalans were found to be good indicators of environmental pollution. This review summarizes current knowledge of acanthocephalans as human parasites and their beneficial uses.
\end{abstract}

Keywords: Acanthocephala, Acanthocephalus, Bolbosoma, Corynosoma Macracanthorhynchus, Moniliformis, Plagiorhynchus, Pseudoacanthocephalus

Received: 23 October, 2020, Accepted: 10 December, 2020.

Corresponding Author: Wael M Lotfy, Tel.: +20 1272688624, E-mail: waelotfy@mau.edu.eg

Print ISSN: 1687-7942, Online ISSN: 2090-2646, Vol. 13, No. 3, December, 2020.

Acanthocephalans (Phylum Acanthocephala) are a mysterious group of parasites. Adults are cylindrical unsegmented worms. They vary greatly in length from a few millimetres to $65 \mathrm{~cm}$ as in Macracanthorhynchus hirudinaceus. However, most of the known species have an average length of 10-35 $\mathrm{mm}$. Worms are characterized by having an invaginable proboscis armed with spines used to attach to the intestinal wall of the vertebrate host. They have a hollow trunk which contains the excretory, reproductive and nervous systems in psuedocoelomic fluid. Acanthocephalans are dioecious, with separate male and female worms. They lack an alimentary tract, and the absorption of nutrients occurs entirely through the body wall. They have a pair of oval bodies called lemnisci, which hang from the anterior wall of the body and extend into the trunk. Each lemniscus serves as a fluid reservoir when the proboscis is invaginated, and may also have a function in fat metabolism ${ }^{[1,2]}$. Phylogenetic studies have indicated that acanthocephalans are highly derived rotifers ${ }^{[3]}$.

Acanthocephalans are exclusively parasitic in all classes of vertebrates, especially in fish and birds. They have complex life cycles which involve at least two hosts (Figure 1). In species with known life cycle, juveniles colonise arthropods (crustaceans or insects), and adults colonise vertebrates (fish, amphibians, reptiles, birds or mammals). The eggs are passed in faeces of the final host to be eaten by the intermediate host. Some species have more than one intermediate host. Some vertebrates act as paratenic hosts for the larval stages that need to be ingested by the appropriate vertebrate host in order to develop into adults ${ }^{[1]}$.

The phylum Acanthocephala comprises four classes: Archiacanthocephala, Eoacanthocephala, Palaeacanthocephala, and Polyacanthocephala.
Adults of the class Archiacanthocephala are microscopic parasites that attach themselves to the intestinal wall of terrestrial vertebrates. They infect mainly predacious birds and mammals. Adults of the class Eoacanthocephala are parasites of fishes and less frequently amphibians and reptiles. The class Palaeacanthocephala is the largest and most diversified class of acanthocephalans. Adults of this class parasitize fishes, amphibians, reptiles, birds, and mammals throughout the world. The class Polyacanthocephala comprises only one monogeneric family that parasitizes crocodiles and probably fish in South America and Africa, respectively ${ }^{[4-7]}$.

\section{Human acanthocephaliasis}

Humans have been associated with acanthocephalans since antiquity. Their eggs were detected in fossilized human excrement (coprolites) that was dated to the prehistoric era ${ }^{[8,9]}$. Human cases of acanthocephaliasis are only common in certain foci in China, and remain sporadic in the rest of the world ${ }^{[10]}$. Many acanthocephalan species are known to have low host specificity but fortunately, for ecological reasons, are not likely to be ingested by $\operatorname{man}^{[11]}$. Man was reported to be infected with at least nine acanthocephalan species, among them, Macracanthorhynchus hirudinaceus and Moniliformis moniliformis are the most common species ${ }^{[12,13]}$. Most reported cases of acanthocephaliasis have involved the gastrointestinal tract. Acanthocephalans of medical importance are found only in two classes, Archiacanthocephala, and Palaeacanthocephala. Species of the former class are relatively large, while species of the latter are small.

1. Class: Archiacanthocephala Macracanthorhynchus hirudinaceus (Pallas, 1781) Synonyms: Taenia hirudinaceus (Pallas, 1781); Gigantorhynchus gigas (Pallas, 1781). 


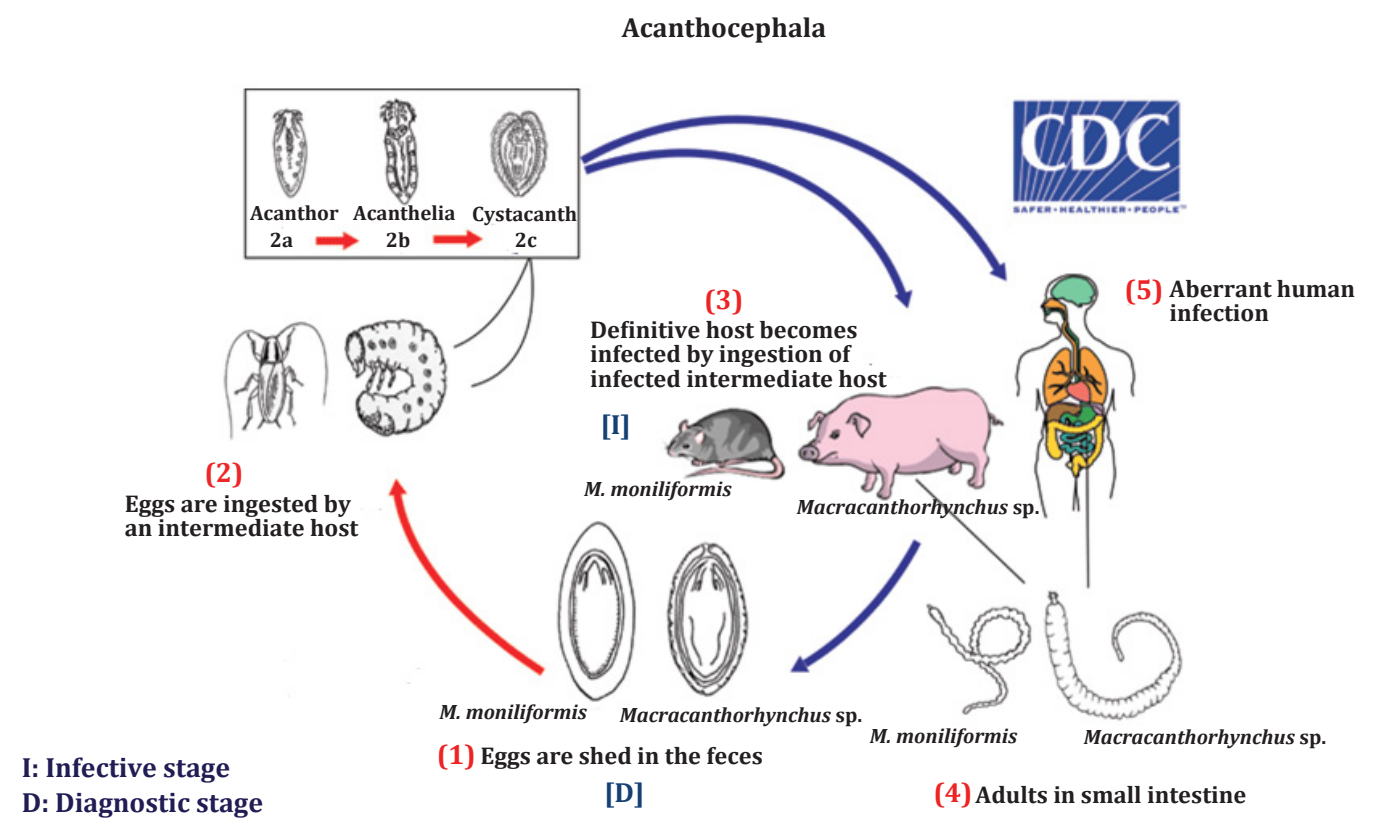

Fig. 1. The life cycles of Macracanthorhynchus sp. and Moniliformis moniliformis, and transmission of human acanthocephaliasis (source: https://www.cdc.gov)

This species has a cosmopolitan distribution ${ }^{[14]}$. The definitive hosts of this species are pigs and other suids, and very rarely dogs and human. Adult worms colonize the small intestine of the mammalian host, and embryonated eggs, containing a fully developed acanthor, are expelled with the faeces. To continue their development, the egg must be ingested by a beetle, usually a dung beetle. Inside the intermediate host, the egg hatches in the midgut and the freed acanthor larva migrates to the body cavity of the insect, where it continues its development to reach the acanthellae stage, then encysts to form the cystacanth stage. When a definitive host ingests a parasitized insect, the larva sheds its cystic envelope and, after 2-3 months, reaches maturity and begins oviposition ${ }^{[15]}$.

Human infection usually occurs in regions of high prevalence of $M$. hirudinaceus in pigs and human habits of consumption of raw or under roasted insects, for dietary or medicinal purposes ${ }^{[10]}$. After ingestion, the parasite attaches itself firmly to the intestinal mucosa by using its proboscis. This may result in inflammation and granuloma formation. The parasite may penetrate the intestinal wall to reach the peritoneum. Mechanical damage caused by the insertion of the armed proboscis into the intestinal wall may result is acute abdominal pain, eosinophilic enteritis and possibly intestinal perforation with peritonitis and abscess formation. Some cases in China have had acute abdominal colic with multiple perforations in the jejunum ${ }^{[16]}$.

In 1859, Lambl documented the first report of acanthocephaliasis in man when he diagnosed a child infection in Prague, Czech lands ${ }^{[17]}$. More cases were reported from Russia ${ }^{[18-20]}$, Brazil ${ }^{[21]}$, Thailand ${ }^{[22-25]}$, Madagascar $^{[26]}$, Papua New Guinea ${ }^{[27]}$, and China ${ }^{[16,28]}$.

\section{Macracanthorhynchus ingens Meyer, 1933}

This species exists almost exclusively in North America $^{[29]}$. The life cycle of $M$. ingens is greatly like that of M. hirudinaceus. Definitive hosts for $M$. ingens include raccoons, wolves, badgers, foxes, skunks, opossums, mink, bears, ring-tailed cats, moles and $\operatorname{dogs}^{[30,31]}$. The definitive host becomes infected by ingesting an intermediate host, a millipede, containing the infective cystacanth stage of the parasite or by ingesting a paratenic host, such as a rodent or a snake, containing encysted cystacanths. After ingestion, the cystacanth hatches in the small intestine of the host, attaches its proboscis deep into the intestinal wall, and matures to the adult stage ${ }^{[32]}$. It was reported that $M$. ingens was not a significant zoonotic parasite but was diagnosed in few cases of children in Texas, USA ${ }^{[29,33]}$.

Moniliformis moniliformis (Bremser, 1811) Travassos, 1915

This species is a common parasite found in most parts of the world ${ }^{[12]}$. The life cycle is like the above mentioned two archiacanthocephalans. The definitive host for $M$. moniliformis is typically a rat, although other rodents, carnivores, and primates including man, may serve as accidental hosts. The parasite's eggs are ingested by an intermediate host (typically a cockroach or beetle), which is subsequently eaten by the definitive host, resulting in infection. Infected cockroaches showed reduced predator avoidance behaviour, a phenomenon that presumably benefits the parasite by increasing the likelihood that its cockroach host will be 
ingested by a rodent, a necessary event for the parasite to complete its life cycle ${ }^{[34]}$. Amphibians and reptiles may serve as paratenic hosts ${ }^{[35]}$.

Humans, especially children, may acquire the infection by ingesting cockroaches and beetles containing infective larva ${ }^{[36,37]}$. It is probable that human infection is acquired by eating a raw paratenic host. In infected human hosts, the worms seldom mature or mature but do not produce eggs. In Zimbabwe, spurious human infections were reported in people for whom rodents comprised part of their $\operatorname{diet}^{[38]}$. One of the interesting reports was that by Grassi and Calandruccio in 1888 who reported the symptoms shown by the second author after voluntarily infecting himself with M. moniliformis ${ }^{[39]}$. Manifestations described in the different reports varied from asymptomatic passage of worms to loss of appetite, weight loss, severe abdominal pain, diarrhoea, fever, general malaise, vomiting, retarded development, and irritability ${ }^{[37]}$.

Cases of human infection by $M$. moniliformis have been reported from Israel ${ }^{[40]}$, USA ${ }^{[41-45]}$, Madagascar ${ }^{[46]}$, $\operatorname{Iran}^{[12,47-50]}$, Zimbabwe (Rhodesia) ${ }^{[51]}, \operatorname{Egypt}^{[52]} \operatorname{Iraq}^{[53]}$, Australia ${ }^{[5,55]}$, China ${ }^{[56]}$, Japan ${ }^{[57]}$ Nigeria ${ }^{[58,59]}$, and $\mathrm{KSA}^{[37]}$.

\section{Class: Palaeacanthocephala}

Compared with the class Archiacanthocephala, acanthocephalans belonging to this class were reported relatively few times in humans.

\section{Acanthocephalus rauschi Golvan, 1969}

Little is known about the geographical distribution of this parasite. This species infects humans very rarely with only one documented report. The life cycle is unknown. It was suggested that infection may result from ingestion of an infected intermediate or paratenic host. The parasite was recovered from the peritoneum of an Inuit (Eskimo) in Alaska ${ }^{[60]}$.

Bolbosoma Porta, 1908 (unidentified species)

Only scanty information is available about the biogeography of the different species belonging to this genus. In addition, the life cycle of the genus Bolbosoma has not yet been completely confirmed. It has been suggested that marine mammals, especially whales, are the definitive host, and crustaceans are the first intermediate host. Most probably, some species of marine fishes may act as a paratenic host ${ }^{[61,62]}$. Accidentally, these worms may infect humans. The parasite inhabits the human jejunum and may cause acute peritonitis by perforating the intestinal wall. The specimens recovered from most cases were incomplete or sexually immature, hence species identification is unconfirmed. Up to now, at least seven cases of human Bolbosoma infection, all from Japan, have been reported ${ }^{[63-70]}$. These cases are most probably infected by eating infected raw marine fish as "sashimi", a traditional Japanese dish ${ }^{[63]}$.
Corynosoma strumosum (Rudolphi, 1802) Lühe, 1904

The precise biogeography of this parasite is unknown. Definitive hosts of this species are fisheating mammals, particularly seals, and birds. The intermediate host is probably a crustacean. Many species of fish serve as paratenic hosts ${ }^{[62]}$. This species was reported once from man, but accidental parasitism of Eskimos is probably common. One juvenile specimen was recovered from the stools of an Eskimo male in Alaska after treatment with atabrine. It is probable that the man became infected by eating raw fish containing an encysted worm ${ }^{[11]}$.

\section{Corynosoma validum Van Cleave, 1953}

Little is known about the biogeography of this species. Its life cycle is like that of $C$. strumosum. The definitive hosts are mainly walruses and seals ${ }^{[71]}$. The intermediate host is probably a crustacean. Several species of fishes are known to be paratenic hosts ${ }^{[72]}$. Human infection with fully mature $C$. validum worm was reported only once in Japan ${ }^{[14]}$.

\section{Plagiorhynchus sp. Lühe, 1911}

Adult worms of the genus Plagiorhynchus are intestinal parasites of birds in different parts of the world. The intermediate host of this species is usually an arthropod. There is only one unusual report of an immature acanthocephalan, probably Plagiorhynchus sp., retrieved from a gardener's eye in Kent, England. Most probably the parasite was accidentally transferred from the environment to the pateints's eye, possibly by his own hands ${ }^{[73]}$.

Pseudoacanthocephalus bufonis (Shipley, 1903) Petrochenko, 1956

Synonym: Acanthocephalus bufonis (Shipley, 1903) Southwell and Macfie, 1925.

Adult worms of this species are long known common parasite of amphibians in south-eastern Asia ${ }^{[74,75]}$. It was recently introduced into Hawaii ${ }^{76]}$. The life cycle and the intermediate hosts are unknown. In 1954, four male acanthocephalans were recovered from the small intestine of an Indonesian man during a routine autopsy at the Medical School in Djakarta, Indonesia. The worms were reported as Acanthocephalus sp. ${ }^{[77]}$. However, the species was identified later as Pseudoacanthocephalus bufonis ${ }^{[11]}$.

Beneficial use of acanthocephalans: The different acanthocephalan species have been found to accumulate high quantities of heavy metals compared to their hosts. Thus, it was recommended to use them as bioindicators of heavy metal pollution and environmental deterioration especially in aquatic ecosystems ${ }^{[78-81]}$.

Prevention and control: Almost all species of acanthocephalans can only be transmitted to human by ingestion of an infected arthropod intermediate host, or a vertebrate paratenic host. In other words, most 
acanthocephaliasis cases are due to dietary mistakes, either because of eating raw fish or of ingesting insects. Thus, the most effective mean of prevention is avoiding ingestion of the incriminated species in a raw form. In case of $M$. hirudinaceus, swine should be kept under hygienic conditions and provided with abundant food to discourage rooting and ingestion of beetles.

Treatment: Pyrantel pamoate ${ }^{[42]}$ and ivermectin ${ }^{[59]}$ have been reported as the drug of choice for the treatment of moniliformiasis. In many cases diagnosis is made after emergency surgery. However, in some reports the adult worm was expelled and identified after the patient was treated with piperazine citrate ${ }^{[82]}$.

Conclusion: Few human cases of acanthocephaliasis have been reported worldwide, most of which have been caused by the species $M$. moniliformis. None of the reported species are a specific human parasite or occur regularly in him. Human infection seems to reflect localised dietary habits or aberrations. Despite their economic and medical significance, acanthocephalans were found to be good bioindicators of heavy metal pollution and environmental deterioration especially in aquatic ecosystems.

Conflict of interest: There is no conflict of interest.

\section{REFERENCES}

1. Nickol BB. Epizootiology. In: Crompton DWT, Nickol BB, editors. Biology of the Acanthocephala. Cambridge, UK: Cambridge University Press; 1985, p. 307-346.

2. Dunagan TT, Miller DM. Acanthocephala. In: Harrison FW, editor. Microscopic anatomy of invertebrates: Aschelminthes. New York, NY: Wiley-Liss; 1991, p. 299332.

3. Near TJ. Acanthocephalan phylogeny and the evolution of parasitism. Integr Comp Biol 2002;42(3):668-677.

4. Amin OM. Key to the families and subfamilies of Acanthocephala, with the erection of a new class (Polyacanthocephala) and a new order (Polyacanthorhynchida). J Parasitol 1987;73(6):12161219.

5. Amin OM, Dezfuli BS. Taxonomic notes on Polyacanthorhynchus kenyensis (Acanthocephala: Polyacanthorhynchidae) from Lake Naivasha, Kenya. J Parasitol 1995; 81(1):76-79.

6. Amin OM. Marine flora and fauna of the eastern United States: Acanthocephala. Seattle, Washington: US Department of Commerce; 1998.

7. Amin OM. Classification of the acanthocephala. Folia Parasitol (Praha) 2013;60(4):273-305.

8. Moore JG, Fry GF, Englert EJ. Thorny-headed worm infection in North American prehistoric man. Science 1969; 163(3873):1324-1325.

9. Goncalves ML, Araujo A, Ferreira LF. Human intestinal parasites in the past: new findings and a review. Mem Inst Oswaldo Cruz 2003; 98 Suppl 1:103-118.
10. Taraschewski H. Host-parasite interactions in Acanthocephala: A morphological approach. Adv Parasit 2000; 46:1-179.

11. Schmidt GD. Acanthocephalan infections of man, with two new records. J Parasitol 1971;57(3):582-584.

12. Berenji F, Fata A, Hosseininejad Z. A case of Moniliformis moniliformis (Acanthocephala) infection in Iran. Korean J Parasitol 2007; 45(2):145-148.

13. Takahashi K, Ito T, Sato T, Goto M, Kawamoto T, Fujinaga $\mathrm{A}$, et al. Infection with fully mature Corynosoma cf. validum causes ulcers in the human small intestine. Clin J Gastroenterol 2016; 9: 114-117.

14. Golvan YJ. Nomenclature of the Acanthoccphala. Res Rev Parasitol 1994;54:135-205.

15. Schmidt GD. Development and life cycles. In: Crompton DWT, Nickol BB, editors. Biology of the Acanthocephala: Cambridge University Press; 1985, p. 273-305.

16. Leng YJ, Huang WD, Liang PN. Human infection with Macracanthorhynchus hirudinaceus Travassos, 1916 in Guangdong Province, with notes on its prevalence in China. Ann Trop Med Parasitol 1983; 77(1):107-109.

17. Lambl VDF. Mikroskopische Untersuchungen der Darm-Excrete. Beitrag zur Pathologie des Darms und zur Diagnostik am Krankenbette. Vierteljahrschrift für die praktische Heilkunde Herausgegeben von der medicinischen Facultät in Prag 1859; 1:1-58.

18. Lindemann K. Zur Anatomie der Acanthocephalen. Bulletin de la Société Impériale des Naturalistes de Moscou 1865; 38:483-98.

19. Schneider A. LV. On the development of Echinorhynchus gigas. Ann Mag Nat Hist (Series 4) 1871; 7(42):441-443.

20. Skrinnik MR, Likhotinskaya MV, Ocheret AM. A case of Macracanthorhynchus infection in man. Med Parazitol (Mosk) 1958; 27(4):450-451.

21. Gonzaga AG. Assumptos de Actualidade. Contribuição ao saneamento do Nordeste. Brazil-Medico 1921; 35:134135.

22. Pradatsundarasar A, Pechranond K. Human infection with the acanthocephalan Macracanthorhynchus hirudinaceus in Bangkok: report of a case. Am J Trop Med Hyg 1965; 14(5):774-776.

23. Kliks M, Tantachamrun T, Chaiyaporn V. Human infection by an acanthocephalan Macracanthorhynchus hirudinaceus in Thailand: new light on a previous case. Southeast Asian J Trop Med Public Health 1974; 5(2):303-309.

24. Hemsrichart V, Pichyangkura C, Chitchang S, Vutichamnong U. Eosinophilic enteritis due to Macracanthorhynchus hirudinaceus infection: report of 3 cases. J Med Assoc Thai 1983; 66(5):303-310.

25. Radomyos P, Chobchuanchom A, Tungtrongchitr A. Intestinal perforation due to Macracanthorhynchus hirudinaceus infection in Thailand. Trop Med Parasitol 1989; 40(4):476-477.

26. Voelckel J, Cathalan G. Parasitism in humans due to Macracanthorhynchus hirudinaceus (Pallas 1781) on Madagascar. Med Trop (Mars) 1968; 28(2):139-142.

27. Barnish G, Misch KA. Unusual cases of parasitic infections in Papua New Guinea. Am J Trop Med Hyg 1987; 37(3):585-587. 
28. Li T, He S, Zhao H, Zhao G, Zhu XQ. Major trends in human parasitic diseases in China. Trends Parasitol 2010; 26(5):264-270.

29. Brien JH, Fader R, Wehbe-Janek H. Successful treatment of Macracanthorhynchus ingens infection with mebendazole. J Pediatric Infect Dis 2012; 7(4):161-163.

30. Richardson DJ, Owen WB, Snyder DE. Helminth parasites of the raccoon (Procyon lotor) from northcentral Arkansas. J Parasitol 1992; 78(1):163-166.

31. Pearce JR, Hendrix CM, Allison N, Butler JM. Macracanthorhynchus ingens infection in a dog. J Am Vet Med Assoc 2001; 219(2):194-196.

32. Moore DV. Studies on the life history and development of Macracanthorhynchus ingens Meyer, 1933, with a redescription of the adult worm. J Parasitol 1946; 32:387-399.

33. Dingley D, Beaver PC. Macracanthorhynchus ingens from a child in Texas. Am J Trop Med Hyg 1985; 34:918-920.

34. Libersat F, Moore J. The parasite Moniliformis moniliformis alters the escape response of its cockroach host Periplaneta americana. J Insect Behav 2000; 13(1):103-110.

35. Baumholtz MA, Parish LC, Witkowski JA, Nutting WB. The medical importance of cockroaches. Int J Dermatol 1997; 36(2):90-96.

36. Marty AM. Cockroaches can vector human diseases. Int J Dermatol 1998; 37(8):639-640.

37. Makki SM, Madani TA, Al Mohsen IZ, Almodovar EL. A child with an acanthocephalan infection. Ann Saudi Med 2006; 26(4):321-324.

38. Prior C, Goldsmid J. M. moniliformis sp. as a spurious parasite of man. J Assoc Med Lab Technol Rhodesia 1974; 3:21-22.

39. Grassi GB, Calandruccio S. Ueber einen Echinorhynchus: welcher auch im Menschen parasitirt und dessen Zwischenwirt ein Blaps ist. Zbl Bakt Hyg 1 Abt Orig 1888; 3:521-525.

40. Witenberg G. Some unusual observations on helminthiasis in Israel. Harefuah 1951; 41(10):179-180.

41. Beck JW. Report of a possible human infection with the acanthocephalan Moniliformis moniliformis (syn. M. dubius). J Parasitol 1959; 45(5):510.

42. Counselman K, Field C, Lea G, Nickol B, Neafie R. Moniliformis moniliformis from a child in Florida. Am J Trop Med Hyg 1989; 41(1):88-90.

43. Neafie RC, Marty AM. Unusual infections in humans. Clin Microbiol Rev 1993; 6(1):34-56.

44. Messina AF, Wehle FJ, Jr., Intravichit S, Washington K. Moniliformis moniliformis infection in two Florida toddlers. Pediatr Infect Dis J 2011; 30(8):726-727.

45. Andres JM, English JE, Greiner EC. Acanthocephalan infection probably associated with cockroach exposure in an infant with failure-to-thrive. Pediatr Infect Dis 2014; 6(2):63-65.

46. Dulac P, Ralaimihoatra R. The first case in Madagascar of parasiticinfection in man with Moniliformis moniliformis. Revue de Medecine et d'Hygiene Tropicales 1963; 35 (314):2.

47. Sahba GH, Arfaa F, Rastegar M. Human infection with Moniliformis dubius (Acanthocephala) (Meyer, 1932). (syn. M. moniliformis, (Bremser, 1811) (Travassos, 1915) in Iran. Trans R Soc Trop Med Hyg 1970; 64(2):284-286.

48. Moayedi B, Izadi M, Maleki M, Ghadirian E. Human infection with Moniliformis moniliformis (Bremser, 1811) Travassos, 1915 (syn. Moniliformis dubius). Report of a case in Isfahan, Iran. Am J Trop Med Hyg 1971; 20(3):445-448.

49. Salehabadi A, Mowlavi G, Sadjjadi SM. Human infection with Moniliformis moniliformis (Bremser 1811) (Travassos 1915) in Iran: another case report after three decades. Vector Borne Zoonotic Dis 2008; 8(1):101-103.

50. Rokni MB. The present status of human helminthic diseases in Iran. Ann Trop Med Parasitol 2008; 102(4):283-295.

51. Goldsmith JM, Smith ME, Fleming F. Human infection with Moniliformis sp. in Rhodesia. Ann Trop Med Parasitol 1974; 68(3):363-464.

52. Rysavy B, Barus V. Moniliformis dubius Meyer, 1933 (Acanthocephala) in Egypt. Folia Parasitol (Praha) 1975; 22(3):282.

53. Al-Rawas AY, Mirza MY, Shafig A, Al-Kindy L. First finding of Moniliformis moniliformis (Bremser 1811) Travassos 1915 (Acanthocephala: Oligacanthorhynchidae) in Iraq from human child. J Parasitol 1977; 63(2):396-397.

54. Provic P, Walker J, Crompton LJ, Tristram SG. First record of human acanthocephalan infections in Australia. Med J Aust 1990; 152(4):215-216.

55. Bettiol S, Goldsmid JM. A case of probable imported Moniliformis moniliformis infection in Tasmania. J Travel Med 2000; 7(6):336-337.

56. Mao SP. Protozoan and helminth parasites of humans inmainland China. Int J Parasitol 1991; 21:347-351.

57. Miyazaki I. Acanthocephaliasis. Helmithic zoonoses. Tokyo, Japan: International Medical Foundation of Japan; 1991, p. 466-471.

58. Ikeh EI, Anosike JC, Okon E. Acanthocephalan infection in man in northern Nigeria. J Helminthol 1992; 66(3):241-242.

59. Anosike JC, Njoku AJ, Nwoke BE, Okoro OU, Okere AN, Ukaga CN, et al. Human infections with Moniliformis moniliformis (Bremser 1811) Travassos 1915 in south-eastern Nigeria. Ann Trop Med Parasitol 2000; 94(8):837-838.

60. Golvan YJ. Systematique des acanthocephales (Acanthocephala Rudolphi 1801). Premiere partie. L'ordre des Palaeacanthocephala Meyer 1931. Premier fascicule. La super-famille des Echinorhynchoidea (Cobbold 1876) Golvan et Houin 1963. Mem Mus Natl Hist Nat 1969; 47:1-373.

61. Van Cleave HJ. Acanthocephala of North American mammals. Urbana: The University of Illinois Press; 1953.

62. Yamaguti S. Systema helminthum. 5. Acanthocephala New York, NY: Interscience Publisher Inc.; 1963.

63. Tada I, Otsuji Y, Kamiya H, Mimori T, Sakaguchi Y, Makizumi S. The first case of a human infected with an acanthocephalan parasite, Bolbosoma sp. J Parasitol 1983; 69(1):205-208.

64. Beaver PC, Otsuji T, Otsuji A, Yoshimura H, Uchikawa R, Sato A. Acanthocephalan, probably Bolbosoma, from the 
peritoneal cavity of man in Japan. Am J Trop Med Hyg 1983; 32(5):1016-1018.

65. Ishikura HA, Takahashi S, Sato N, Kon S, Oku Y, Kamiya $\mathrm{M}$, et al. Perforative peritonitis by the infection with young adult female of Bolbosoma sp.: A case report. Jpn J Parasitol 1996; 45:518-524.

66. Mori S, Maeba T, Sekimata T, Kobayashi S, Suguri S, Harada M. A human infection with Bolbosoma sp., accidentally found in the operation for gastric cancer. Clin Parasitol 1998; 9:35-37.

67. Kobayashi T, Kin S, Funabiki S, Sasahara H, Kida Y, Bunno M, et al. A case report of duodenal Bolbosoma incidentally found by screening endoscopy. Gastroenterol Endosc 2002; 44(12 ):2083-2086.

68. Hino Y, Tsuchihashi Y, Kobayashi M, Arizono N, Kagei N. Infection with Bolbosoma sp. (Acanthocephala) in man: Report of a case. Clin Parasitol 2002; 13:102-104.

69. Isoda K, Kuroda M, Shimizu T, Okumura E. A case of gastric acanthocephalan infection, Bolbosoma sp., found by gastroendoscopy. Clin Parasitol 2006; 17:8388.

70. Arizono N, Kuramochi T, Kagei N. Molecular and histological identification of the acanthocephalan Bolbosoma cf. capitatum from the human small intestine. Parasitol Int 2012; 61(4):715-718.

71. Van Cleave HJ. A preliminary analysis of the acanthocephalan genus Corynosoma in mammals of North America. J Parasitol 1953; 39(1):1-13.

72. Shults LM, Frost KJ. Helminth parasites of ribbon seals, Phoca fasciata, in the Bering Sea and their intermediate hosts. Proc Helminthol Soc Wash 1988; 55(1):68-73.

73. Haustein T, Lawes M, Harris E, Chiodini PL. An eyecatching acanthocephalan. Clin Microbiol Infect 2010; 16(6):787-788.

74. Yuen PH, Fernando LH. On Acanthocephalus bufonis (Shipley) a common parasite of Malayan amphibians. Bull Nat Mus Singapore 1967; 33:91-93.
75. Bush SE, Duszynski DW, Nickol BB. Acanthocephala from amphibians in China with the description of a new species of Pseudoacanthocephalus (Echinorhynchida). J Parasitol 2009; 95(6):1440-1445.

76. Barton DP, Pichelin S. Acanthocephalus bufonis (Acanthocephala) from Bufo marinus (Bufonidaei Amphibia) in Hawaii. Parasite 2014; 6(3):269-272.

77. Joe LK, Siang TK. Human intestinal helminths obtained from autopsies in Djakarta, Indonesia. Am J Trop Med Hyg 1959; 8(4):518-523.

78. Schludermann C, Konecny R, Laimgruber S, Lewis JW, Schiemer F, Chovanec A, et al. Fish macroparasites as indicators of heavy metal pollution in river sites in Austria. Parasitology 2003; 126:S61-69.

79. Sures B. Fish acanthocephalans of the genus Pomphorhynchus sp. as globally applicable bioindicators for metal pollution in the aquatic environment? Wien Klin Wochenschr 2004; 116(4):19-23.

80. Jankovska I, Miholova D, Lukesova D, Kalous L, Valek P, Romocusky S, et al. Concentrations of $\mathrm{Zn}, \mathrm{Mn}, \mathrm{Cu}$ and $\mathrm{Cd}$ in different tissues of perch (Perca fluviatilis) and in perch intestinal parasite (Acanthocephalus lucii) from the stream near Prague (Czech Republic). Environ Res 2012; 112:83-85.

81. Paller VG, Resurreccion DJ, de la Cruz CP, Bandal MZ, Jr. Acanthocephalan parasites (Acanthogyrus sp.) of Nile tilapia (Oreochromis niloticus) as biosink of lead (pb) contamination in a Philippine freshwater lake. Bull Environ Contam Toxicol 2016; 96(6):810-815.

82. Acha PN, Szyfres B. Zoonoses and communicable diseases common to man and animals. $3^{\text {rd }}$ ed. Washington DC: Pan American Health Organization; 2003. 